\title{
Outcome of orthotopic liver transplantation in patients with haemophilia
}

\author{
F H Gordon, P K Mistry, C A Sabin, C A Lee
}

\begin{abstract}
Background-Many patients with haemophilia have developed cirrhosis or hepatocellular carcinoma due to transfusion acquired chronic viral hepatitis.

Aims-To assess the long term outcome of all haemophilic patients reported to have undergone orthotopic liver transplantation.

Methods-Transplant centres of patients identified by medical database search were contacted and survival data assessed by Kaplan-Meier analysis.

Results-Twenty six haemophilic men (median age 46 years, range 5-63 years) underwent orthotopic liver transplantation in 16 centres between 1982 and 1996. Indications for transplantation were hepatitis C cirrhosis (69\%), hepatitis $B$ with or without $C$ cirrhosis $(15 \%)$, viral hepatitis related hepatocellular carcinoma (12\%), and biliary atresia (4\%). Six patients (23\%) were infected with human immunodeficiency virus (HIV). Postoperatively, the median time to normal clotting factor levels was 24 hours (range $0-48$ hours) and exogenous clotting factors were stopped at a median of 24 hours (range 0-480 hours). Four patients $(15 \%)$ had bleeding complications. The one and three year survival of HIV positive recipients (67\% and $23 \%$ ) was significantly poorer $(p=0.0003)$ than that of HIV negative recipients $(90 \%$ and $83 \%)$. Coagulopathy was cured in all patients surviving more than 12 days post-transplant. Six of the 20 patients $(30 \%)$ with hepatitis $C$ cirrhosis pretransplant had evidence of disease recurrence at a mean of nine months post-transplant.

Conclusions-Hepatitis C cirrhosis is the most common indication for orthotopic liver transplantation in patients with haemophilia. Transplantation results in long term cure of haemophilia but may be complicated by the effects of HIV infection or recurrent viral hepatitis.

(Gut 1998;42:744-749)
\end{abstract}

Haemophilia and Haemostasis Centre, Royal Free Hospital School of Medicine, London

C A Lee

Correspondence to: Dr F H Gordon, Department of Medicine, Royal Free Hospital Schoo of Medicine, Rowland Hill Street, London NW3 2PF UK.

Accepted for publication 18 December 1997 infection acquired from non-sterilised clotting factor concentrates prior to 1985 . Liver transplantation may be the only potentially curative treatment available to these patients, as antiviral drugs such as $\alpha$ interferon ( $\alpha$-IFN) are of limited benefit. ${ }^{1}$ The demand for transplantation is likely to increase in view of the fact that virtually all patients with haemophilia who have received non-virus inactivated clotting factors have been infected with $\mathrm{HCV}^{2}$ and at least $30 \%$ of these patients are expected to develop cirrhosis. ${ }^{3}$ Starzl's group performed the first successful orthotopic liver transplantation (OLT) in a patient with haemophilia in Pittsburgh in $1985^{4}$ and since then there have been individual case reports of a further 24 liver transplants in haemophilic patients. ${ }^{5-21}$ Two studies, which included the data from the first 11 haemophilic OLT patients, have reported the long term survival of such patients. ${ }^{12} 22$

Anticipated difficulties of OLT in haemophilic patients include perioperative management of coagulopathy, recurrence of viral hepatitis, and problems related to human immunodeficiency virus (HIV) infection. Various strategies of clotting factor replacement exist and one aim of this study was to try to identify both the most successful method and the optimal duration of infusion postoperatively. Additionally, we aimed to assess the long term outcome of OLT in haemophilic patients in terms of survival, cure of coagulopathy, and complication frequency.

\section{Methods}

Case reports of haemophilic patients who had received OLT were obtained from the Medline medical journal database. The transplantation centre of each patient was contacted by letter and telephone to obtain further information of long term outcome. One unpublished case was identified in the course of communication. Survival rates as of 1 December 1996 were tested for significance using the log rank test. All statistical analyses were carried out using the LIFETEST procedure of the Statistical Analysis System (SAS). ${ }^{23}$

\section{Results}

\section{PATIENT DEMOGRAPHY}

Twenty six male haemophilic patients underwent OLT in 16 centres between 1982 and 1996 (table 1). The mean age at time of surgery was 39 years (median 46 years, range 5-63). Twenty one patients had haemophilia A, three had haemophilia $B$, one patient had both diseases with B predominant, and one patient had factor $\mathrm{X}$ deficiency. Information on haemophilia severity was available for 24 patients, of whom 13 (54\%) were described by authors as having severe disease, four (17\%) moderate, and seven (29\%) mild disease. There was no recorded evidence of an inhibitor to factor VIIIC in any patient pretransplant. 
Table 1 Details of 26 haemophilic orthotopic liver transplant patients

\begin{tabular}{|c|c|c|c|c|c|c|c|}
\hline $\begin{array}{l}\text { Patient } \\
\text { no }\end{array}$ & Reference & Transplant centre & $\begin{array}{l}\text { Haemophilia } \\
\text { type }\end{array}$ & Aetiology & $\begin{array}{l}\text { Age at } \\
O L T(y)\end{array}$ & $\begin{array}{l}\text { OLT survival } \\
\text { (months) }\end{array}$ & $\begin{array}{l}\text { HIV } \\
\text { status }\end{array}$ \\
\hline 1 & Bontempo et ă & University of Pittsburgh, USA & A & NANB $(\mathrm{C} \pm \mathrm{B})$ & 21 & 0 & + \\
\hline 2 & Bontempo et al̆ & University of Pittsburgh, USA & A & NANB $(\mathrm{C} \pm \mathrm{B})$ & 16 & 44 & + \\
\hline 3 & Bontempo et a $\bar{l}$ & University of Pittsburgh, USA & A & NANB (C) & 48 & 4 & + \\
\hline 4 & Bontempo et a $\bar{l}$ & University of Pittsburgh, USA & A & NANB (C) & 47 & $124+$ & - \\
\hline 5 & Gibas et al ${ }^{\circ}$ & Massachusetts General Hospital, USA & A & NANB $(C)$ & 36 & 27 & + \\
\hline 6 & Merion et $a l^{7}$ & University of Michigan, Ann Arbor, USA & B & B & 14 & 30 & - \\
\hline 7 & Scharrer et al $l^{\beta}$ & University Hospital, Frankfurt, Germany & A & $\mathrm{B}, \mathrm{C}, \mathrm{D}+\mathrm{HCC}$ & 46 & 59 & - \\
\hline 8 & Delorme $e t a l^{9}$ & University of Western Ontario, London, Canada & $A+B$ & $\mathrm{C}$ & 38 & $75+$ & - \\
\hline 9 & Makris et $a l^{10}$ & Queen Elizabeth Medical Centre, Birmingham, UK & A & $\mathrm{C}$ & 63 & 78 & - \\
\hline 10 & Makris et $a l^{10}$ & Queen Elizabeth Medical Centre, Birmingham, UK & A & $\mathrm{C}+\mathrm{HCC}$ & 57 & $72+$ & - \\
\hline 11 & Deshayes et $a l^{11}$ & CHU, Caen, France & A & $\mathrm{C}$ & 53 & $70+$ & - \\
\hline 12 & $\begin{array}{l}\text { Fischbach and } \\
\text { Scharrer }{ }^{12}\end{array}$ & University Hospital, Frankfurt, Germany & A & $\mathrm{C}$ & 47 & $67+$ & - \\
\hline 13 & Lerut et $a l^{13}$ & University Hospital St Luc, Brussels, Belgium & A & $\mathrm{C}$ & 50 & $96+$ & - \\
\hline 14 & Lerut $e t a l^{13}$ & University Hospital St Luc, Brussels, Belgium & A & $\mathrm{C}$ & 19 & $50+$ & - \\
\hline 15 & Federici et $a l^{14}$ & Ospedale Maggiore, Milan, Italy & A & $\mathrm{B}, \mathrm{C}+\mathrm{D}$ & 27 & $36+$ & - \\
\hline 16 & Kadry et $a l^{15}$ & University Hospital, Geneva, Switzerland & $\mathrm{B}$ & $\mathrm{B}+\mathrm{C}$ & 44 & $31+$ & - \\
\hline 17 & Stangl et $a l^{16}$ & Ludwig Maximilians University, Munich, Germany & A & C & 63 & $48+$ & - \\
\hline 18 & Magallon et $a l^{17}$ & Hospital La Paz, Madrid, Spain & A & Biliary atresia & 5 & $15+$ & - \\
\hline 19 & Hanley et $a l^{18}$ & King's College Hospital, London, UK & A & $\mathrm{C}$ & 36 & $13+$ & + \\
\hline 20 & McCarthy et $a l^{19}$ & King's College Hospital, London, UK & A & $\mathrm{C}$ & 46 & $29+$ & - \\
\hline 21 & McCarthy et $a l^{19}$ & King's College Hospital, London, UK & $\begin{array}{l}\text { Factor X } \\
\text { deficiency }\end{array}$ & $\mathrm{C}$ & 54 & $21+$ & - \\
\hline 22 & McCarthy et $a l^{19}$ & King's College Hospital, London, UK & A & $\mathrm{C}$ & 26 & 15 & + \\
\hline 23 & McCarthy et $a l^{19}$ & King's College Hospital, London, UK & B & $\mathrm{C}$ & 48 & 12 days & - \\
\hline 24 & $\begin{array}{l}\text { Bassendine } M \\
\text { (personal } \\
\text { communication) }\end{array}$ & Freeman Hospital, Newcastle upon Tyne, UK & A & $\mathrm{C}+\mathrm{HCC}$ & 50 & 6 & - \\
\hline 25 & Hanley et $a l^{0}$ & Royal Infirmary, Edinburgh, UK & A & $\mathrm{C}+\mathrm{HCC}$ & 58 & $7+$ & - \\
\hline 26 & Baudo et al $l^{1}$ & Ospedale Niguarda, Milan, Italy & A & $\mathrm{B}, \mathrm{C}+\mathrm{D}$ & 25 & $7+$ & - \\
\hline
\end{tabular}

NANB, non-A non-B hepatitis; +, patient alive on 12 December 1996.

Six patients were known to be HIV positive prior to transplantation; one patient had had Pneumocystis carinii pneumonia, an acquired immunodeficiciency syndrome (AIDS) defining illness, 20 months prior to transplantation. The mean time to development of hepatic decompensation from the date of first clotting factor concentrate infusion was 17 years (median 16 years, range 5-33) in 15 patients for whom the information was available. The mean time from detection of abnormal liver function tests to hepatic decompensation was nine years (median 11 years, range 2-21) in those 15 patients for whom this information was available.

INDICATIONS FOR TRANSPLANTATION

Twenty five patients $(96 \%)$ had developed liver cirrhosis as a consequence of transfusion acquired viral hepatitis. Decompensated HCV cirrhosis was the main indication for transplantation in 18 patients (69\%), one of whom was found to have coexistent hepatocellular carcinoma (HCC) at surgery. Five of these patients (patients 1 to 5) were transplanted before the introduction of $\mathrm{HCV}$ testing, and retrospective sera were not available. However, physicians at their centres held the opinion that they should be assumed to have had HCV cirrhosis; three of these patients had chronic non-A non-B hepatitis (patients 3, 4, and 5) and the remaining two were hepatitis B surface antigen (HBsAg) positive but had no serological evidence of active HBV infection. Patient 1 had antibodies to HBsAg and patient 2 had had persistent antibodies to hepatitis $\mathrm{B}$ e antigen (HBeAg) since early childhood. Four patients had cirrhosis related to HBV with or without HCV or HDV coinfection (15\%): two patients were coinfected with $\mathrm{HBV}$ and $\mathrm{HCV}$; one patient was coinfected with $\mathrm{HBV}, \mathrm{HCV}$, and
HDV; and one patient had HBV alone. HCC was the main indication for transplantation in three patients $(12 \%)$, of whom one had HBV, $\mathrm{HCV}$, and HDV coinfection and the remaining two had evidence of $\mathrm{HCV}$ infection alone. A five year old patient underwent transplantation on account of biliary cirrhosis, which he had developed following a Kasai procedure performed during infancy for congenital biliary atresia.

MANAGEMENT OF PERIOPERATIVE COAGULOPATHY Nineteen of the 21 patients for whom the information was available received an initial loading dose of the appropriate clotting factor substitute at induction, followed either by a continuous infusion intraoperatively (seven patients) or by a further bolus intraoperatively (12 patients), the dose of which was dependent on coincident plasma clotting factor measurements. Two patients with mild haemophilia required no exogenous clotting factors perioperatively. The mean bolus dose used at induction was $56 \mathrm{U} / \mathrm{kg}$ (range 38-80 U/ $\mathrm{kg}$ ) and the intraoperative infusion rate varied from 2 to $7 \mathrm{U} / \mathrm{kg}$ per hour. Those centres which used a second intraoperative bolus dose used a dose varying between 25 and $50 \mathrm{U} / \mathrm{kg}$ according to intraoperative clotting values. Three patients received additional infusions of either heparin or aprotinin. The time at which clotting factor treatment was stopped was available for 21 patients and varied from immediately to 480 hours (20 days) postoperatively; patients 5 and 13 received clotting factors for 10 and 20 days post-transplant, respectively. Slow production of endogenous factor VIII appeared to be the reason for this delay in patient 5 , but there is no clear explanation for this in patient 13. The mean time at which exogenous clotting factor treatment was stopped was 53 hours (median 


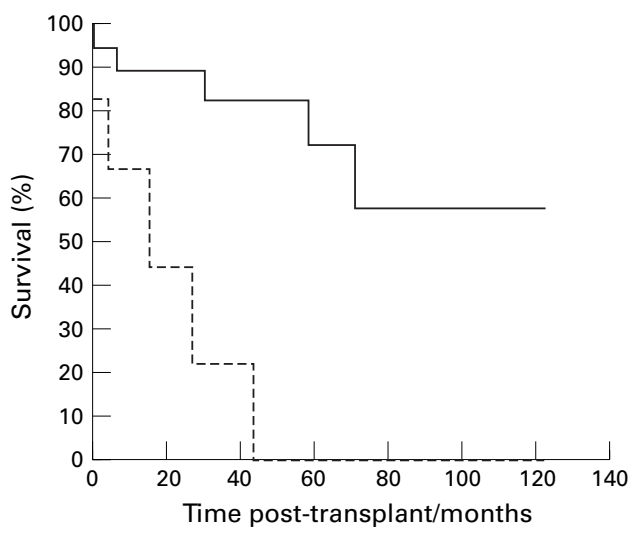

Figure 1 Kaplan-Meier survival probability plot of 26 haemophilic orthotopic liver transplant recipients. Continuous line indicates HIV negative recipients; dotted line indicates HIV positive recipients.

24 hours), or 20 hours if patients 5 and 13 are excluded. Eight patients stopped receiving exogenous clotting factors immediately postoperatively. Excluding patients 5 and 13, the mean time to achieving normal factor VIII, IX, or X post-transplant of the 16 other patients for whom this information was available was 20 hours (median 24 hours, range $0-48$ ).

\section{IMMUNOSUPPRESSION}

All patients received prednisolone and either cyclosporin (21 patients) or tacrolimus (five patients), with or without azathioprine as initial immunosuppression at doses standard for OLT. The initial dose of immunosuppressant drugs given to HIV positive patients was similar to that of HIV negative patients. Prednisolone was withdrawn completely in 14 of the 20 patients for whom this information was available.

OUTCOME

Survival

Overall post-transplant survival at one and three years was $83 \%$ and $68 \%$, respectively. One and three year survival of 19 HIV negative patients was $90 \%$ and $83 \%$, respectively, which is significantly better $(p=0.0003)$ than that of six HIV positive patients, whose one and three year survival was $67 \%$ and $23 \%$, respectively (fig 1). One HIV positive patient died intraoperatively, but AIDS related illnesses directly accounted for the deaths of at least three HIV positive patients $(2,3$, and 5$)$ who died at 44,4 , and 27 months post-transplant, respectively. Two of these patients (2 and 5) returned to work or school prior to the onset of AIDS. Patient 22 died from a combination of hepatorenal syndrome and sepsis following severe cholestatic HCV recurrence, which may have been related to concurrent $\mathrm{HIV}$ infection, in that he had weight loss greater than $10 \mathrm{~kg}$ within one month at 14 months post-OLT and thus met AIDS diagnostic criteria at the time of death. One HIV positive patient (patient 19) has survived 15 months post-OLT and has returned to work, despite a low preoperative CD4+ lymphocyte count of 160 cells $/ \mathrm{mm}^{3}$ and prior AIDS defining illness.

Five of the 20 HIV negative patients have died since transplantation; the death of only one patient can be directly attributed to the procedure: patient 6 died at 30 months post-transplant, aged 16 years, from septicaemia following a strangulated small intestinal hernia adjacent to his Roux-en-Y hepaticojejunostomy. Three patients died from causes unrelated to transplantation: patient 7 committed suicide at 59 months post-transplant, aged 51 years; patient 9 died, aged 69 years, from congestive cardiac failure related to a dilated cardiomyopathy at 78 months post-transplant; and patient 24 died from metastatic HCC at six months post-transplant, aged 50 years, HCC having been the main indication for his transplant. Patient 23 died from an acute subdural haemorrhage at 12 days postoperatively, aged 48 years. This may have been related to transplantation, since the bleed occurred at the site of a small chronic subdural haematoma noted preoperatively. Additionally, the patient was receiving low dose intravenous heparin to facilitate dialysis for probable cyclosporin induced nephropathy at the time of the haemorrhage.

\section{Coagulopathy: cure and complications}

Long term phenotypic cure of haemophilia was achieved in all 24 patients who survived for more than 12 days post-transplant. Four patients developed bleeding complications, which were fatal in two patients: patient 1 died from intraoperative blood loss which was due to complicated surgery, rather than inadequate clotting factor replacement; and the death of patient 23 has been described above. Patient 3 returned to theatre two days post-transplant on account of intra-abdominal bleeding but no distinct bleeding point was found. Patient 22 also underwent laparotomy on account of a retroperitoneal haemorrhage on the third postoperative day. Patients 3, 22, and 23 had normal prothrombin times and factor VIII/IX levels detected at the time of their bleeds. None of the eight patients whose exogenous clotting factor infusions were stopped immediately postoperatively developed bleeding complications.

\section{Recurrence of viral hepatitis}

Six of the 20 patients $(30 \%)$ with cirrhosis or HCC related to HCV pretransplant developed biopsy evidence of recurrence at a mean of nine months from transplantation. Initially, this took the form of periportal inflammation in all but patient 22, who developed a severe cholestatic form of HCV at six months post-OLT. Disease recurrence in patients 8 and $13(10 \%)$ resulted in cirrhosis at seven and five years from transplantation, respectively. Three patients received ribavirin $(20,21$, and 22$)$; this had little effect in patient 22 and it is still too early to assess improvement in the other two patients. Three of the five patients with HBV related liver disease pre-OLT developed disease recurrence despite receiving perioperative hepatitis B immunoglobulin; patients 6,7 , and 15 developed hepatitis at days 26,48 , and 12 months respectively. All three patients had HCV coinfection and the HBV-DNA state was positive preoperatively only in patient 15; 


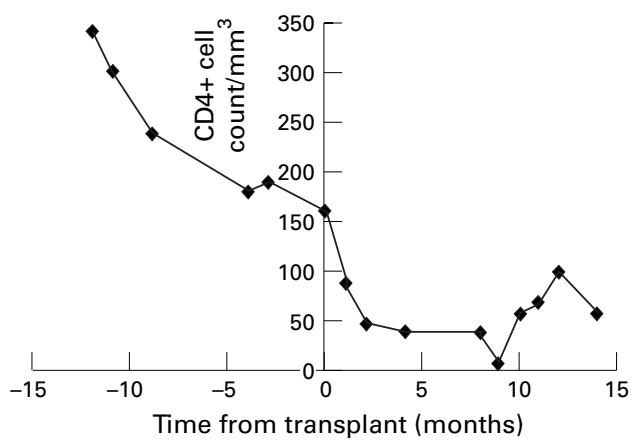

Figure 2 Serial CD4+ lymphocyte counts of HIV positive patient 19 before and after transplantation.

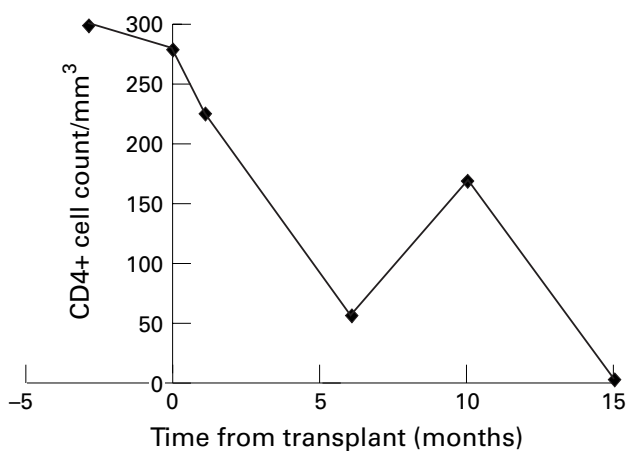

Figure 3 Serial CD4+ lymphocyte counts of HIV positive patient 22 before and after transplantation.

patient 7 was negative and the HBV-DNA state of patient 6 was unknown. Patients 7 and 15 were both delta antibody positive; the delta status of patient 6 was unknown.

\section{HIV related complications}

The CD4+ lymphocyte counts of patients 2, 3, 19 , and 22 at surgery were $434,285,160$, and 280 cells $/ \mathrm{mm}^{3}$, respectively. Patient 5 had a low CD4+:CD8+ cell ratio of 0.27 prior to transplantation and the preoperative $\mathrm{CD} 4+$ lymphocyte count of patient 1 was unknown. The duration of HIV infection prior to surgery was known in patients 19 and 22 to have been at least 12 and five years, respectively. This information was not available for the four other HIV positive patients, but patients 2,3 , and 5 had all received non-sterilised clotting factor concentrates for at least 12 years prior to transplantation. Four patients (2, 3, 5, and 22) developed AIDS at a mean of 18 months posttransplant (range 3-41 months) and died at a mean of 22 months (range 4-44 months). Patient 1 died intraoperatively as described earlier. Patients 5, 19, and 22 received zidovudine at 24,5 , and 14 months post-transplant, respectively, on account of persistently low CD4+ lymphocyte counts. Additionally, patient 22 received saquinavir, an HIV protease inhibitor at nine months post-transplant. Figures 2 and 3 respectively show serial CD4+ lymphocyte counts of patients 19 and 22 postOLT.

Other complications

Twelve patients developed acute rejection for which nine patients received intravenous methylprednisolone and the remaining three were given OKT3 antilymphocyte globulin. Three patients developed cytomegalovirus hepatitis which was likely to be related to concurrent $\mathrm{HIV}$ infection in one patient only. Late complications included the development of anastomotic biliary strictures in two patients, chronic rejection necessitating retransplantation after four years in one patient, and idiopathic renal impairment in one patient.

\section{Discussion}

\section{DEMOGRAPHY}

Most patients in this series suffered from severe haemophilia, which is consistent with other groups who have found the risk of developing chronic liver disease to be associated with increased clotting factor consumption. ${ }^{24}$ The mean time of 17 years from date of first use of clotting factors to onset of decompensated liver disease is similar to estimates made in other studies. ${ }^{25}$ If the only patient without viral hepatitis (patient 18) is excluded, this figure rises to 18 years (range 10-33 years). The figure for mean time to development of abnormal liver function tests is unlikely to be representative of actual liver damage, as many haemophilic patients did not have regular liver function tests performed until the discovery of the risks of $\mathrm{HCV}$ in the late 1980s. HCV cirrhosis or HCV related HCC was the main indication for OLT in 20 patients $(77 \%)$ in this series. The number of such patients is likely to continue to increase, given that haemophilic patients did not receive virus inactivated clotting factors until 1985 and the mean time to decompensation is at least 18 years from clotting factor infusion. Furthermore, haemophilic patients with HCV infection often respond poorly to $\alpha$-IFN,${ }^{1}$ which may result in a higher proportion requiring liver transplantation than in the non-haemophilic population. It is also likely that many $\mathrm{HCV}$ infected haemophilic patients will require OLT on account of HCC, as the incidence of this tumour in haemophilic patients with chronic viral hepatitis is estimated to be 30 times that of the general population. ${ }^{26}$

\section{COAGULOPATHY: MANAGEMENT AND CURE}

Most centres used a method of bolus injection followed either by further boluses or by a continuous infusion of the appropriate clotting factor concentrate. The choice of method appeared to be dependent on the facilities available at the time of surgery, rather than haemophilia severity, as no patients transplanted prior to 1991 received a bolus-infusion regimen. Continuous infusions have the advantage of maintaining a constant level of clotting factors in addition to being more economicalone third less expensive than twice daily boluses. ${ }^{27}$ Numbers in this series are too small to be able to make any statistical correlation between frequency of bleeding complications and the type of clotting factor replacement regimen used; patient 22 received an infusion and patient 23 received boluses of clotting factors. For the same reason, no correlation can be made between the time to normal clotting development and replacement regimen used. Interestingly, the mean time to development of 
normal clotting values post-transplant was 20 hours which is similar to that of nonhaemophilic patients; Stahl et al reported normalisation of the prothrombin time to occur between 24 and 120 hours posttransplant, ${ }^{28}$ the time being dependent on graft function and operative blood loss. Furthermore, eight of these 16 patients $(50 \%)$ received no exogenous clotting factors post-transplant, suggesting that haemophilic liver transplant patients may not necessarily require any further clotting factor replacement postoperatively, except in the situations of poor initial graft function or large volume intraoperative blood loss.

The frequency of bleeding complications $(15 \%)$ is consistent with that reported from series of non-haemophilic patients undergoing OLT. ${ }^{29}$ McCarthy et al noted that the development of a fatal subdural haemorrhage in patient 23 was probably related to a previous small chronic subdural haematoma seen on a preoperative computed tomography (CT) scan and suggest that previous subdural haemorrhage might be considered as a relative contraindication to OLT in haemophilic patients. ${ }^{19}$ Evidence of cerebral haemorrhage was shown by CT scan in $2.4 \%$ of a series of 124 moderate to severe haemophilic patients ${ }^{30}$ and it may therefore be prudent to perform preoperative cerebral CT scans in such patients.

The results of this series of patients confirm overwhelmingly that liver transplantation offers patients with haemophilia long term cure of their coagulopathy. In the UK the cost of the procedure is at least $£ 45000$ (approximately US $\$ 73000)^{31}$ but this is offset by the savings incurred from stopping clotting factor replacements, which for a severely affected patient requiring approximately 100000 units factor VIII/IX can amount to as much as $£ 30000$ (US $\$ 50$ 000) per annum. In addition, the quality of life of haemophilic patients is greatly improved by no longer having to self administer intravenous clotting factors regularly.

OUTCOME

The survival figures for HIV negative patients are similar to those reported in other HBV and HCV series. ${ }^{32}{ }^{33}$ As might be predicted, survival of the HIV positive patients in this series was poor and the preoperative CD4+ lymphocyte count did not necessarily predict outcome. It is important to note that the numbers in this series are small and that two of the five deaths in the HIV positive group were not due to AIDS. Interestingly, the patient with the lowest CD4+ lymphocyte count preoperatively (patient $19 ; 160$ cells $/ \mathrm{mm}^{3}$ ) has had a relatively uncomplicated post-transplant recovery. Postoperatively, his count has remained less than 100 cells $/ \mathrm{mm}^{3}$, despite treatment with an HIV protease inhibitor. It is difficult to know whether this low count is a result of transplantation and immunosuppression (fig 2), or a consequence of $\mathrm{HCV}$, as his $\mathrm{HCV}$ genotype (type 1) has been associated with an increased rate of progression to AIDS in haemophilic patients. ${ }^{34}$ The fact that viral hepatitis itself may affect the post-transplant survival of HIV posi- tive patients is suggested by a series of recipients from Pittsburgh who were known to be HIV positive prior to transplantation, in whom the postoperative survival of liver transplant recipients was notably poorer than that of recipients of other organs. ${ }^{35}$ Patient age at transplantation also seems to determine the outcome of HIV positive recipients; the children in this series had better long term survival. At least $70 \%$ of $\mathrm{HCV}$ infected haemophilic patients have HIV coinfection. ${ }^{36}$ Although such patients have a higher prevalence of severe liver disease ${ }^{24} 37$ than their HIV negative counterparts, many transplant centres may feel that OLT cannot be justified in patients whose post-transplant survival is anticipated to be short. This argument is supported by long term follow up studies of non-haemophilic transplant patients with HIV infection. ${ }^{35} 38{ }^{39}$ The advent of zidovudine and HIV protease inhibitors has lengthened the time to development of AIDS in HIV positive patients ${ }^{40}{ }^{41}$ and hence may potentially improve the post-transplant survival of future recipients.

Recurrence of viral hepatitis post-transplant is a problem common to haemophilic and nonhaemophilic patients alike. A longitudinal study of a series of 149 patients reported by Gane et al showed that $27 \%$ of patients transplanted on account of $\mathrm{HCV}$ cirrhosis developed a moderate chronic hepatitis at a median of 35 months and cirrhosis developed in $8 \%$ at a median of 51 months. ${ }^{33}$ Furthermore, $\mathrm{HCV}$ recurrence has been suggested to be more severe in those patients who are HCV genotype $1 \mathrm{~b}$ preoperatively, ${ }^{42}$ although this view has been contested. ${ }^{43}$ Genotype 1 is most commonly found in UK haemophilic patients ${ }^{44}$ suggesting that as a group they may have a higher risk of developing graft recurrence of HCV. HIV infection is thought to enhance the replication of $\mathrm{HCV}^{45}$ although the mechanism remains unknown and this effect is likely to persist post-transplantation. In this context, patients 19 and 23 had early evidence of graft recurrence of $\mathrm{HCV}$ at seven and six months respectively. Notably, that of patient 23 took the form of aggressive cholestasis which has been reported by other groups ${ }^{46}$ although its significance in relation to the patient's HIV status is unclear.

Hepatitis B recurred in three of the five patients who had HBV related liver disease pretransplant, all of whom were HIV negative. The risk of post-transplant HBV recurrence has been reported to be approximately $58 \%$ in those patients who are HBV-DNA negative preoperatively and $83 \%$ in those DNA positive, but its frequency has been found to be reduced to $36 \%$ in those patients given antihepatitis B surface antigen immunoglobulin for at least six months post-transplant. ${ }^{32}$ Post-transplant lamivudine prophylaxis may also be useful in preventing relapse, particularly in those patients who are HBV-DNA positive at the time of surgery. ${ }^{47}$ In addition, HBV recurrence is less frequent in recipients with concurrent $\mathrm{HCV}$ infection. ${ }^{48}$ 
CONCLUSIONS

Orthotopic liver transplantation provides long term phenotypic cure of haemophilia. The survival of HIV negative haemophilic recipients is similar to that of non-haemophilic recipients transplanted for HCV cirrhosis and bleeding complications are no more frequent. Clotting factor replacement at time of surgery is probably best managed by continuous infusion and may be stopped immediately postoperatively in those patients with good graft function and low volume intraoperative blood loss. Post-transplant survival of HIV positive haemophilic patients is poorer than that of HIV negative recipients, although quality of life is dramatically improved by curing haemophilia and by permitting some to return to work. The small number of cases performed by each centre makes management guidelines difficult to devise except by multicentre analysis. We therefore propose to maintain an international register of haemophilic liver transplant patients at the Haemophilia Centre and Haemostasis Unit at the Royal Free Hospital and invite centres to report cases not described herein.

We are indebted to Dr P C Adams, Professor M Bassendine, Dr F Bontempo, Dr L Caccamo, Miss E Currie, Dr A Derlon, Dr J P Deshayes, Dr J L Dienstag, Dr E Elias, Professor D Galmarini, Dr H Hambley, Dr J P Hanley, Dr M Hudson, Dr V Jimenez Yuste, Mrs T Joy, Dr E Lavenne-Pardonge, Dr J W Locke, Dr C A Ludlam, Dr M McCarthy, Dr G Mentha, Dr R Merion, Dr J Neuberger, Dr J O'Grady, Dr G Piseddu, Professor R E Pounder, Dr M Ragni, Ms P Rioch, Professor I Scharsor R E Pounder, Dr M Ragni, Ms P Rioch, Professor I Scharrer, Dr P Segol, Dr M Stangl, and Professor R Williams. FHG
is supported by a grant from Athena Neurosciences (Europe) is supp.

1 Devereux H, Telfer P, Dusheiko G, et al. Hepatitis C genotypes in hemophilic patients treated with $\alpha$-interferon. $f$ Med Virol 1995;45:284-7.

2 Watson HG, Ludlam CA, Rebus S, et al. Use of several second generation serological assays to determine the true prevalence of hepatitis $\mathrm{C}$ virus infection in haemophiliacs treated with non-virus inactivated factor VIII and IX concentrates. Br f Haematol 1992;80:514-8.

3 Tremolada F, Casarin C, Alberti A, et al. Long-term follow-up of non-A non-B (type C) post-transfusion hepatitis. F Hepatol 1992;16:273-81.

4 Lewis JH, Bontempo FA, Spero JA, et al. Liver transplantation in a hemophiliac. N Engl f Med 1985;312:1189-90.

5 Bontempo FA, Lewis JH, Gorenc TJ, et al. Liver transplanBontempo FA, Lewis JH, Gorenc TJ, et al. Live

6 Gibas A, Dienstag JL, Schafer AI, et al. Cure of hemophilia A by orthotopic liver transplantation. Gastroenterology 1988;95:192-4

7 Merion RM, Delius RE, Campbell DA, et al. Orthotopic liver transplantation totally corrects factor IX deficiency in hemophilia B. Surgery 1988;104:929-31.

8 Scharrer I, Encke A, Hottenrott C. Clinical cure of haemophilia A by liver transplantation. Lancet $1988 ;$;i: $800-1$.

9 Delorme MA, Adams PC, Grant D, et al. Orthotopic liver transplantation in a patient with combined hemophilia A and B. Am F Hematol 1990;33:136-8.

10 Makris M, Preston FE, Triger T, et al. Liver transplantation in haemophilia [abstract]. Thromb Haemost 1991;65:1157.

11 Deshayes JP, Tartiere J, Samba D, et al. Evolution du facteur de coagulation VIII apres transplantation hepatique chez un malade hemophile A. Presse Med 1992;21:216.

12 Fischbach P, Scharrer I. Therapeutic impact of orthotopic liver transplantation on disorders of hemostasis. Semin liver transplantation on disor
Thromb Hemost 1993;19:250-7.

13 Lerut JP, Laterre PF, Lavenne-Pardonge E, et al. Liver transplantation and hemophilia Am f Hepatol 1995;22: 583-5.

14 Federici AB, Mannucci PM, Stabile F, et al. Orthotopic liver transplantation in a patient with severe hemophilia A: life-saving treatment for the first Italian case. Int $\mathcal{F}$ Clin Lab Res 1995;25:44-6

15 Kadry Z, de Moerloose P, Giostra E, et al. Orthotopic liver transplantation in hemophilia B: a case report. Transpl Int 1995;8:485-7.

16 Stangl MJ, Anthuber M, Pape GR, et al. Lebertransplantation bei Hamophilie A? Internist (Berl) 1995;36:56-61.

17 Magallon M, Jimenez Yuste V, Jara P, et al. Phenotypic cure of haemophilia A by orthotopic liver transplantation of haemophilia A by orthotopic liver trans
[abstract]. Haemophilia 1996;2(suppl 1):103.

18 Hanley JP, Jarvis LM, Ellis AJ, et al. The role of liver transplantation in a severe haemophiliac co-infected with HCV and HIV [abstract]. Haemophilia 1996;2(suppl 1):103.
19 McCarthy M, Gane E, Pereira S, et al. Liver transplantation for haemophiliacs with hepatitis C cirrhosis. Gut 1996;39: $870-5$.

20 Hanley JP, Hayes PC, Lowe GDO, et al. Hepatocellular carcinoma in haemophilia [abstract]. Thromb Haemost 1997; 77(suppl 1):454.

21 Baudo F, Caimi TM, Redailli R, et al. Orthotopic liver transplantation in a patient with severe hemophilia A and advanced liver cirrhosis [abstract]. Thromb Haemost 1997; 77(suppl 1):163.

22 Ragni MV, Bontempo FA, Lewis JH. Organ transplantation in HIV-positive patients with hemophilia $N$ Engl $\mathcal{F} \mathrm{Med}$ 1990:322:1886-7.

23 SAS Institute Inc. SAS/STAT users' guide, version 6. 4th edn. Carey, NC: SAS Institute Inc., 1989.

24 Eyster ME, Diamondstone LS, Lien JM, et al. Natural history of hepatitis $\mathrm{C}$ virus infection in multitransfused hemophiliacs: effect of coinfection with human immunodeficiency virus. The Multicenter Hemophilia Cohort Study. f Acquir Immune Defic Syndr Hum Retrovirol 1993;6:60210 .

25 Makris M, Preston FE, Rosendal FR, et al. The natural history of chronic hepatitis $\mathrm{C}$ in haemophiliacs. Br $\mathcal{F}$ Haematol 1996;94:746-52.

26 Colombo M, Mannucci PM, Brettler DB, et al. Hepatocellular carcinoma in hemophilia. Am f Hematol 1991;37:2436.

27 Lee CA. Hope for haemophilic patients with hepatitis. Gut 1996;39:887-8.

28 Stahl RL, Duncan A, Hooks MA, et al. A hypercoagulable state follows orthotopic liver transplantation. Hepatology 1990;12:553-8.

29 Ozaki CF, Katz SM, Monsour HP, et al. Surgical complications of liver transplantation. Surg Clin North Am 1994;74: $1155-67$

30 Wilson DA, Nelson MD, Fenstermacher MJ, et al. Brain abnormalities in male children and adolescents with hemophilia: detection with MR imaging. Radiology 1992; 185:553-8.

31 Supra Regional Services Advisory Group. Annual report 1995-96. London: Wellington House, 1996.

32 Samuel D, Muller R, Alexander G, et al. Liver transplantation in European patients with the hepatitis B surface antigen. N Engl f Med 1993;329:1842-7.

33 Gane EJ, Portmann BC, Naoumov NV, et al. Long-term outcome of hepatitis $\mathrm{C}$ infection after liver transplantation. $N$ Engl F Med 1996;334:815-20.

34 Sabin CA, Telfer P, Phillips AN, et al. The association between hepatitis $C$ virus genotype and human immunodeficiency virus disease progression in a cohort of hemophilic men. F Infect Dis 1997;175:164-8.

35 Tzakis AG, Cooper MH, Dummer JS, et al. Transplantation in HIV+ patients. Transplantation 1990;49:354-8.

36 Goedert JJ, Kessler CM, Aledort LM, et al. A prospective study of human immunodeficiency virus type 1 infection and the development of AIDS in subjects with hemophilia. N Engl F Med 1989;321:1141-8.

37 Telfer P, Sabin C, Devereux H, et al. The progression of HCV associated liver disease in a cohort of haemophilic patients. Br f Haematol 1994;87:555-61.

38 Dummer JS, Erb S, Breinig MK, et al. Infection with human immunodeficiency virus in the Pittsburgh transplant population. A study of 583 donors and 1043 recipients, 1981-1986. Transplantation 1989;47:134-40.

39 Erice A, Rhame FS, Heussner RC, et al. Human immunodeficiency virus infection in patients with solidorgan transplants: report of five cases and review. Rev Infect Dis 1991;13:537-47.

40 Delta Coordinating Committee. Delta: a randomized double-blind controlled trial comparing combinations of zidovudine plus didanosine or zalcitabine with zidovudine alone in HIV-infected individuals. Lancet 1996;348:283-

41 Collier AC, Coombs RW, Schoenfeld DA, et al. Treatment of human immunodeficiency virus infection with saquinavir, zidovudine, and zalcitabine. N Engl f Med 1996;334: vir, zido $101-7$.

42 Gane EJ, Naoumov NV, Qian KP, et al. A longitudinal analysis of hepatitis $\mathrm{C}$ virus replication following liver analysis of hepatitis $C$ virus replication following
transplantation. Gastroenterology 1996;110:167-77.

43 Boker KH, Dalley G, Bahr MJ, et al. Long-term outcome of hepatitis $\mathrm{C}$ virus infection after liver transplantation. Hepatology 1997;25:203-10.

44 Telfer PT, Devereux H, Savage K, et al. Chronic hepatitis C virus infection in haemophilic patients: clinical significance of viral genotype. Thromb Haemost 1995;74:1259-64.

45 Eyster ME, Fried MW, Di Bisceglie AM, et al. Increasing hepatitis C virus RNA levels in hemophiliacs: relationship to human immunodeficiency virus infection and liver disease. Multicenter Hemophilia Cohort Study. Blood 1994:84:1020-3.

46 Schluger LK, Sheiner PA, Thung SN, et al. Severe recurrent cholestatic hepatitis C following orthotopic liver transplantation. Hepatology 1996;23:971-6.

47 Grellier L, Mutimer D, Ahmed M, et al. Lamivudine prophylaxis against reinfection in liver transplantation for hepatitis B cirrhosis. Lancet 1996;348:1212-16.

48 Huang EJ, Wright TL, Lake JR, et al. Hepatitis B and C co-infections and persistent hepatitis $B$ infections: clinical outcome and liver pathology after transplantation. Hepatology 1996;23:396-404. 